\title{
OUT OF AFRICA: EXPLORING THE ETHIOPIAN SENTENCING GUIDELINES
}

\begin{abstract}
To date, the literature on sentencing reform has largely focused on western jurisdictions, particularly the United States and Europe. Developments in other parts of the world, particularly on the African continent, have been overlooked. This article explores sentencing in a lesser-known African jurisdiction: Ethiopia. The focus of the essay is upon the issue of structured sentencing. Sentencing in Ethiopia, like most jurisdictions, has historically been a very discretionary stage of the criminal process. That has now changed with the introduction of a comprehensive guideline scheme. Although sentencing guidelines in the US and England and Wales have been the subject of much critical scrutiny, nonwestern guidelines have attracted very little attention from scholars. Although there are parallels between the structure of the Ethiopian system and guidelines in other countries, there are also important differences. Since they are more developed than guidelines in adjacent countries, the Ethiopian guidelines constitute a model for other regional nations, including those with a post-colonial legacy. After providing an overview of sentencing in Ethiopia, the article describes the origin, nature, and consequences of the Ethiopian guidelines. The guidelines provide sentence ranges for different levels of seriousness for many crimes, and also prescribe a methodology to guide courts sentencing for offences for which no such guidance exists. They also provide some structure for the judicial use of mitigating and aggravating factors at sentencing. We conclude by identifying some deficiencies of the current guidelines and propose some specific remedies.
\end{abstract}

\section{INTRODUCTION}

Ethiopia is one of only two African countries which was not colonized by the European powers. The European legal tradition was imported in 1960 as a result of an initiative undertaken by the King of Ethiopia to modernize the traditional Ethiopian criminal law. These

* Legal Researcher, Amsterdam, The Netherlands and Law School, Jimma University, Jimma, Ethiopia. E-mail: katimola@gmail.com

**Faculty of law, University of Oxford, St Cross Road, Oxford OX1 3UQ, UK. E-mail: julian.roberts@crim.ox.ac.uk 
laws on crime and punishment were found in the Fetha Negest (Laws of Kings), and relate to both ecclesiastical and secular matters. ${ }^{1}$ The first modern penal Code in Ethiopia was proclaimed into law in $1930 .^{2}$ This Code emerged in response to the harsh punishments mandated by the Fetha Negest. The 1930 penal code abolished some of the more extreme punishments (including amputation of a hand as punishment for theft), but retained others which were also excessive even by the standards of the time. ${ }^{3}$ As a result, the Criminal Code (hereafter, simply "Code") became out of date in a relatively short period, due to social and political changes in the 1950s in Ethiopia (and around the world). A more contemporary Code came into force in 1957 and the current sentencing regime in Ethiopia reflects this Code. Finally, the 1957 Penal Code was replaced by the 2004 Criminal Code which introduced amendments to the calculation of sentences and created several new crimes. At the present, sentencing principles and rules stipulated in the 2004 Criminal Code together with the sentencing guideline issued by the Federal Supreme Court constitute the sentencing framework in Ethiopia. The sentencing guideline constitutes the most significant development in Ethiopian sentencing, and is accordingly the subject of this article.

\subsection{Sentencing Guidelines}

Sentencing guidelines were initially proposed in England in the late nineteenth century ${ }^{4}$, and first implemented in the US a century later. ${ }^{5}$ As a result, the ever-growing scholarship on structured sentencing has until now been largely restricted to first world jurisdictions, principally the US and England and Wales. ${ }^{6}$ Scholars have generally

\footnotetext{
${ }^{1}$ See P. L, Strauss, The Fetha Nagast: The law of the Kings (Addis Ababa, Haile Sellassie I University, 1968).

${ }^{2}$ See J. Graven, "The Penal Code of the Empire of Ethiopia", (1964) $1 \mathrm{~J}$. Ethiopian L 267-298.

${ }^{3}$ Graven, J, supra note 2, p. 274.

${ }^{4}$ See Roberts, J.V. (2019) Models of Guidance: Sentencing Guidelines in the England and Wales and the US. In: Crime and Justice. M. Tonry (ed.) Volume 48. Chicago: University of Chicago Press.

${ }^{5}$ Minnesota was the first state to adopt formal, statutorily-binding guidelines in 1980. Other states such as Pennsylvania and Oregon soon followed suit. See R. Frase Forty Years of American Sentencing Guidelines: What have we Learned? in: M. Tonry (ed.) Crime and Justice. Volume 48. Chicago: University of Chicago Press.

${ }^{6}$ See for example Ashworth, A. and Roberts, J.V. (Eds.) (2013) Sentencing Guidelines: Exploring the English Model. Oxford: Oxford University Press. M. Tonry
} 
overlooked developments in the third world, particularly across the continent of Africa. In addition, most of the African scholarship has focused on a single jurisdiction: South Africa. This oversight is regrettable. One of the goals of this article is to shed light on recent innovations and to document progress towards more consistent and principled sentencing in a lesser-known African jurisdiction. Ethiopia is a large, ethnically and linguistically diverse country and in these respects shares characteristics with other countries on the continent. ${ }^{7}$

There are several reasons for exploring the sentencing guidelines conceived and implemented in Ethiopia. First, this jurisdiction has now implemented a comprehensive guidelines scheme, and thereby offers a working example of how an African state has addressed the problem of structuring judicial discretion at sentencing. Kenya and Uganda are the only other jurisdictions to introduce sentencing guidelines, but these schemes are more recent, less well-developed and do not contain specific numerical sentencing recommendations. ${ }^{8}$ Second, the guidelines have been in place for a decade now, permitting some reflections on their impact. Third, Ethiopia's legal framework is rooted in the European legal tradition, and there are therefore important commonalities with sentencing regimes in Europe. Fourth, the Ethiopian guidelines offer a viable model for other regional nations, including those with a post-colonial legacy.

As will be seen, the Ethiopian approach to guidelines is modeled on the guidelines created in England in 2004, rather than the US-style guidelines first implemented in 1980. This suggests that the more discretionary English approach is more likely to be adopted in African jurisdictions. It also suggests a growing international consensus that offence-specific guidelines such as those found in England and Wales and Ethiopia are preferable to the US approach where all

\section{Footnote 6 continued}

(ed.) Sentencing Policies and Practices in Western Countries. Comparative and CrossNational Perspectives. New York: Oxford University Press.

${ }^{7}$ Ethiopia has a population approaching 110 million, with over 80 distinct ethnicities and as many individual languages.

${ }^{8}$ The Kenya guidelines simply direct courts to fix a starting point sentence half way along the statutory sentence range and then to adjust up and down to reflect relevant aggravating and mitigating factors. See J. Kamuzze, Finetuning Uganda's Sentencing Guideline Framework. PhD Thesis, Faculty of Law, University of Strathclyde, 2016; Judiciary of Kenya. Sentencing Policy Guidelines. Supreme Court of Kenya. www.judiciary.go.ke. 
crimes are assigned to a single grid. ${ }^{9}$ Finally, Ethiopia is unique in that it is the first civil law jurisdiction in Africa to adopt a formal guidelines scheme. If the Ethiopian experiment in structuring judicial discretion succeeds, this may well encourage other civil law countries to adopt similar mechanisms.

\subsection{Overview of Essay}

The essay proceeds as follows. We begin with a brief historical background to the sentencing process in Ethiopia. This is followed by a description of the current guidelines. Our discussion locates the guidelines within a limited comparative context, highlighting the elements these guidelines share with other systems (as well as some differences). Finally, we provide some critical commentary, suggesting ways in which they may be improved. Guidelines should evolve; refinements should constantly be undertaken to reflect evolving empirical research and community standards. The US guidelines are reviewed (and often amended), annually by the guidelines authority ${ }^{10}$ in conjunction with the legislature. The English guidelines have also evolved significantly in the decade since the creation of the Sentencing Council in that country. ${ }^{11} \mathrm{~A}$ similar process of self-examination is necessary in Ethiopia.

\section{PART I: SENTENCING FRAMEWORK IN ETHIOPIA}

Ethiopia's statutory sentencing framework provides generic sentencing rules and specific sentencing ranges for individual crimes. As with many European regimes, the 2004 Criminal Code is divided into two parts, a general and a special part. The former specifies generic rules and principles applicable to all crimes, while the latter identifies specific crimes along with their sentencing ranges. The general part

\footnotetext{
${ }^{9}$ For discussion of the merits of the two approaches, see Roberts, supra note 4. Minnesota now three grids, but many hundreds of offences must still be assigned to one of only 11 rows on the grids.

${ }^{10}$ The Minnesota Sentencing Guidelines Commission.

${ }^{11}$ See discussion in Ashworth, A. and Roberts, J.V. (2013) The Origins and Evolution of Sentencing Guidelines in England and Wales. pp. 1-14 in: A. Ashworth and Roberts, J.V. (eds.) Sentencing Guidelines: Exploring the English Model. Oxford: Oxford University Press.
} 
includes a list of mitigating and aggravating circumstances ${ }^{12}$, provisions for the calculation of sentence ${ }^{13}$, rules governing mitigation and aggravation ${ }^{14}$ and enumerates the punishments available to courts at sentencing. ${ }^{15}$ Courts consult these provisions in the general part in determining sentences for crimes in the special part. The penalties for specific crimes are identified in the special part of the Code, normally with wide minimum and maximum limits.

These sentencing provisions are supplemented by the 2010 Ethiopian Federal Supreme Court Sentencing Guidelines. As such, the introduction of the sentencing guidelines in Ethiopia has not replaced the sentencing provisions in the Criminal Code: most of the sentencing provisions in the general part of the Criminal Code still apply. The guideline makes this point quite clear when it states that: "The guideline shall be interpreted in line with the sentencing provisions in the Criminal Code". ${ }^{16}$ In contrast to other jurisdictions that have delegated the responsibility of creating sentencing guidelines to a permanent Commission or Council, the Ethiopian legislator assigned the task of issuing sentencing guideline to the Federal Supreme Court on ad hoc basis. ${ }^{17}$ However, the legislature failed to provide the Supreme Court with the specific authority to issue a sentencing guideline. Article 88 (4) of the Criminal Code simply states that: "In order to ensure consistent sentencing, the Federal Supreme Court shall issue a manual relating to sentencing". The Supreme Court subsequently acted on this authorization and issued its first sentencing guideline which came into effect in May 2010. The guideline has been amended once since then. At present, sentencing rules and principles in the Criminal Code and the sentencing guideline regulate the determination and imposition of sentences in Ethiopia.

\subsection{Statutory Sentencing Objectives}

The utilitarian philosophy, which focuses on preventing crime, predominates in the punishment goals in Ethiopia. This is reflected in the

${ }^{12}$ See Article 82-86, Proclamation No.414/2004, The Criminal Code of The Federal Democratic Republic of Ethiopia ("The Criminal Code").

${ }^{13}$ See Article 88 of the Criminal Code.

${ }^{14}$ See Article 179-189 of the Criminal Code.

15 See Article $90-120$ of the Criminal Code.

${ }^{16}$ Article 4(9), The Revised Sentencing Guideline.

${ }^{17}$ Article 88 of the Criminal Code. 
statutory objectives stipulated by successive penal codes. The primary purpose of the present code is "to ensure the order, peace and the security of the state, its people and inhabitants for the public good" and the prevention of crimes. ${ }^{18}$ Thus, along with crime prevention, the protection of the peace and order of the state and society are the central objectives of the Criminal Code. Article 1 of the Criminal Code also sets out in the purposes of punishment. It provides that:

[The Criminal Code] aims at the prevention of crimes by giving due notice of the crimes and penalties prescribed by law and should this be ineffective, by also providing for the punishment of offenders in order to deter them and others from offending, or by providing for their reform and measures to prevent further crimes.

In addition, the Code expressly emphasizes that penalties should be imposed so as to promote the goals of punishment recognized by the law. ${ }^{19}$ As with other common law jurisdictions, ${ }^{20}$ the goals of punishment in Ethiopia are diverse, and judges are free to choose the punishment goal they believe appropriate in each case. The purposes of punishment include specific and general deterrence and rehabilitation. Article 1 clearly stipulates that punishment can be imposed "for the reform of offenders". ${ }^{21}$ Moreover, the law recognizes various measures that sentencers may employ to reform offenders, including the conditional suspension of punishment. ${ }^{22}$ The prevention of crime through incapacitation is also encompassed in one of the goals of punishment in Ethiopia. The key distinction between the Ethiopian Code and the corresponding statutes in the other jurisdictions ${ }^{23}$ is that retribution is not expressly or implicitly listed as a principle of

${ }^{18}$ Article 1 of the Criminal Code.

${ }^{19}$ Article 87 (1) of the Criminal Code reads: The penalties and measures provided by this Code must be applied in accordance with the spirit of this Code and so as to achieve the purpose it has in vie (Art. 1).

${ }^{20}$ For example, s. 718 of the Canadian Criminal Code enumerates a number of sentencing objectives, as does s. 142 of the Criminal Justice Act 2003 in England and Wales.

${ }^{21}$ Article 1 of the Criminal Code.

22 See Article 90 of the Criminal Code.

${ }^{23}$ For example, s. 781.1 of the Criminal Code of Canada stipulates that: "A sentence must be proportionate to the seriousness of the offence and the offender's degree of responsibility." Similar provisions exist in most other common law jurisdictions. See discussion in: Roberts, J.V. and Baker, E. (2008) Sentencing Structure and Reform in Common Law Jurisdictions. In: S. Shoham, O. Beck, and M. Kett 
punishment. However, this does not mean that courts may ignore proportionality. Consistent with guidelines in other jurisdictions, the sentencing guideline in Ethiopia seeks to promote consistency, predictability, transparency, accountability, and proportionality in sentencing. ${ }^{24}$ Since the goals of punishment in Ethiopia are primarily preventive, one might question whether the desire to promote proportionality through the guideline is compatible with the codified punishment goals. The statute directs courts to pursue utilitarian goals, while as will be seen, the guideline reflects retributivism by promoting the principle of proportionality. This structure may create some tension between the statutory framework and the judiciallyderived guideline.

\subsection{The Principal Sanctions}

Sanctions in Ethiopia are classified as either principal or secondary penalties. The former includes pecuniary penalties, compulsory labour, imprisonment, and the death penalty. ${ }^{25}$ The latter includes cautions, reprimands, admonishment and coerced apologies, and the deprivation of civil rights. ${ }^{26}$ The law also recognizes a separate class of measures and sanctions that apply only to juvenile offenders, which are more pedagogic than punitive; these are not discussed further in this essay. ${ }^{27}$ Ethiopia retains capital punishment for the most serious crimes, although the death penalty is imposed "only in cases of grave crimes and on exceptionally dangerous offenders". 28 Ethiopian courts rarely impose a death sentence and when they do, it is seldom carried out. Over three decades, there have been only two executions, in 1998 and 2007. ${ }^{29}$ Thus, Ethiopia lacks a number of common sanctions such as probation; home confinement and intermittent or conditional imprisonment found in other jurisdictions.

Footnote 23 continued (eds.). International Handbook of Penology and Criminal Justice. New York: Taylor and Francis.

${ }^{24}$ Article 3, The Revised Sentencing Guideline.

${ }^{25}$ See Article $90-120$ of the Criminal Code.

${ }^{26}$ See Article 121-129 of the Criminal Code.

${ }^{27}$ See Article $157-168$ of the Criminal Code.

${ }^{28}$ Article 117(1) of the Criminal Code.

29 For details, see Anonymous, "Ethiopia carries out rare execution", Reuters (6 August 2007), at: http://www.reuters.com/article/idUSL06550887. 
This absence of alternatives undoubtedly contributes to the high use of imprisonment.

\subsubsection{Imprisonment}

Imprisonment is the most frequently-imposed punishment in Ethiopia; courts impose prison sentences even for minor crimes. A prison sentence may be imposed either for a specified period (from 10 days of "simple" custody to 25 years of "rigorous" imprisonment) or for the offender's natural life. As with some other countries ${ }^{30}$, the law recognizes two types of imprisonment - simple imprisonment and "rigorous" imprisonment. The former is imposed for less serious crimes and offenders who do not represent a threat to the community, and normally ranges from ten days to three years. ${ }^{31}$ Exceptionally, however, a court may impose simple imprisonment up to five years when it is warranted by the gravity of the crime. "Rigorous" imprisonment, on the other hand, should be imposed in cases of "very grave crimes committed by offenders who are particularly dangerous to society". 32 The period of rigorous imprisonment extends from one to 25 years or for life. Life imprisonment may only be imposed "where it is expressly so laid down by law". Life imprisonment can legally be imposed only for very serious offences such as crimes against the state, against the military, against international law, and for the most serious crimes against the person.

As provided in the Criminal Code, these forms of imprisonment differ in terms of their potential duration, the offenses for which they may be imposed and the institutions in which they are served. Additionally, the law states that rigorous imprisonment is "intended to provide for a strict confinement of the criminal and for special protection to society". ${ }^{33}$ This suggests a higher level of security accompanied by more intrusive restrictions on inmates' liberty. In reality, however, there is little distinction in the lived experience of prisoners serving these two types of prison sentences. An offender who is sentenced to simple imprisonment is commonly placed in the

\footnotetext{
${ }^{30}$ In Canada, offenders serve shorter prison sentences within provincial jails, and longer terms in federal institutions. The latter are generally harsher and contain higher levels of security. Similarly, in the US, prisoners may serve time in state facilities or federal penitentiaries.

${ }^{31}$ Article 106 of the Criminal Code.

${ }^{32}$ Article 108 of the Criminal Code.

${ }^{33}$ Article 108 of the Criminal Code.
} 
same prison or a wing of a prison and is treated similarly to prisoners serving rigorous imprisonment.

\subsubsection{Financial Penalties}

There are three forms of pecuniary penalties: fines, confiscation, and the appropriation of property. "Restorative" financial penalties are also included under the category of "other pecuniary effects" and these include forfeiture, restitution, and compensation to the victim. ${ }^{34}$ The fine is the most frequently-imposed pecuniary sanction. Fines in Ethiopia may be fixed (e.g., for violations of traffic rules) or discretionary amounts imposed by courts. The former are administered by various government departments and are imposed summarily, while the latter apply to individual and corporate offenders and are determined by courts. Fines may be imposed as a sole penalty, or in addition to or in lieu of other sentences. For individuals, a fine normally ranges from ten to ten thousand $\mathrm{Birr}^{35}$ while fines for corporate offenders are significantly higher. ${ }^{36}$ Article $90(1)$ of the Criminal Code states that ".. in the case of a juridical person, a fine may range from one hundred up to 500,000 Birr." As with other jurisdictions, courts in Ethiopia enjoy wide discretion in determining the amount of fine, although this discretion is now restricted by the sentencing guideline. The Criminal Code provides a non-exhaustive list of key factors which courts should consider when determining the amount of fine, including the offender's culpability, financial capacity, any family responsibilities, as well as his age and state of health. ${ }^{37}$

\subsubsection{Compulsory Labour}

Compulsory labour is not a "stand-alone" sentencing option. Courts may impose this sanction only by converting a fine or simple imprisonment into compulsory labour. A fine may be converted into compulsory labour in the case of fine default. ${ }^{38}$ Compulsory work in lieu of simple imprisonment is a sentence that involves a deduction of wage for the benefit of the state, for a minimum of one day and a

\footnotetext{
${ }^{34}$ See Article 100-102 of the Criminal Code.

35 Article 90 of the Criminal Code.

${ }^{36}$ But a number of special legislations allow the imposition of a fine which is a significantly higher than the maximum provided by the Criminal Code.

${ }^{37}$ Article 90(2) of the Criminal Code.

${ }^{38}$ See Article $95 \& 96$ of the Criminal Code.
} 
maximum of six months. ${ }^{39}$ The prerequisites are that the crime be relatively minor, punishable with simple imprisonment for a term not exceeding six months, and that the offender does not pose a threat to society. ${ }^{40}$ Compulsory work may be imposed either without any restriction of personal liberty, in which case the offender serves the sentence of labour "at the place where he normally works or is employed or in a public establishment or on public works", or with restriction of personal liberty, which requires the offender to discharge the compulsory work by remaining in a particular place of work, or with a particular employer, or in a particular establishment. In this sense, the term "compulsory labour" is misleading, as the substantive penalty bears more resemblance to community service orders found in other jurisdictions. In practice, courts rarely impose this sanction ${ }^{41}$ although it has considerable potential to reduce the prison population, and in a way which benefits the community.

\subsection{Current Problems in Ethiopia Sentencing}

\subsubsection{Disparity in Sentencing}

Prior to the introduction of the sentencing guideline, it was widely believed that sentencing practices in Ethiopia were inconsistent and unpredictable. This perception was shared by the public as well as legal professionals, and ultimately provoked the legislature to create a sentencing guideline. ${ }^{42}$ Reducing disparity was, therefore, one of the principal objectives of the sentencing reform in Ethiopia, although the evidence for disparity was limited in scope. One reason for the paucity of research is that, beyond a doctrinal analysis of legal provisions, there is no culture of empirical research into the justice system. Gross disparity in sentencing was noted by the Supreme Court committee constituted to draft the sentencing guideline. The Committee conducted a small empirical study and concluded that sentencing disparity was a problem. ${ }^{43}$ The committee also concluded

\footnotetext{
${ }^{39}$ See Article 103 \& 104 of the Criminal Code.

${ }^{40}$ Article 103 of the Criminal Code.

${ }^{41}$ One reason is the absence of any responsible authority charged with the task of supervising a work order; another is that there appears only limited awareness on the part of judges about compulsory labour, and the absence of a clear procedure provided by the law itself discourages judges from imposing this sanction.

${ }^{42}$ Article 88(4) of the Criminal Code

${ }^{43}$ See

Mekasha

Abera,

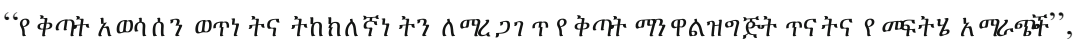


that sentencing was opaque and difficult to comprehend ${ }^{44}$ and that judges were failing to comply with the sentencing rules in the Criminal Code. ${ }^{45}$

\subsubsection{High Use of Custody and State of the Prisons}

Most western nations have struggled in recent decades to reduce or constrain the use of custody as a sanction, and to lower the high numbers of persons in custody. Although systematic statistics on the current prison population are lacking, analysis of the limited data available suggests that the prison population has been rising steeply in recent years. Thus between 2000 and 2010, the prison population almost doubled in size. In 2000, the number of prisoners was 55,$209 ;{ }^{46}$ by 2010 , the prison population had reached $104,467 .{ }^{47}$ The prison population in Ethiopia continues to rise. The latest data available indicate that in $2013-$ 2014, Ethiopia reported the second highest prison rate in Africa, at 127 prisoners per 100,000 population. ${ }^{48}$ Moreover, recent reports also document prison overcrowding and the deterioration of prison conditions. According to a US State Department report in 2017, prison conditions in Ethiopia were unhealthy, unsanitary and "remained harsh and in some cases life-threatening". ${ }^{49}$ Sleeping quarters are grossly overcrowded. For example, it has been reported that "one prison in Asella with capacity for 400 actually held 3,000 inmates". ${ }^{50}$ Prison overcrowding exists in a number of European countries, but not to this extreme extent.

Despite the evidence of overcrowding, there has been no examination of the causes of the increase in the prison population, or discussion of potential remedies. Unlike other jurisdictions where it is

\section{Footnote 43 continued}

( unpublished) at 25, at: https://www.abyssinialaw.com/codes-commentaries-and-ex planatory-notes?download $=1151$ :research-on-sentencing-guidline .

${ }^{44}$ Ibid.

${ }^{45}$ Ibid.

${ }^{46}$ See the ICPS World Prison Brief, Prison data, Ethiopia, available at: http:// www.prisonstudies.org/country/ethiopia.

${ }^{47}$ Ibid.

${ }^{48}$ See the ICPS World Prison Brief, , Highest to Lowest - Prison Population Total, at: http://www.prisonstudies.org/highest-to-lowest/prison-population-total?field_re gion_taxonomy_tid $=15$.

${ }^{49}$ U.S. Department of State, Bureau of Democracy, Human Rights, and Labor, "Ethiopia, Human Rights Report," (2017), p. 3, at: https://www.state.gov/docu ments/organization/277243.pdf.

${ }^{50} \mathrm{Id}$, at 4. 
expressly stated that a prison sentence is a sentence of last resort ${ }^{51}$, no similar policy direction has been proposed by either the legislator or the executive in Ethiopia. The 2003 criminal justice policy initiative addressed the issue only inadequately by placing the responsibility of finding a solution to the problem on the prisons rather than the courts who commit offenders to custody. ${ }^{52}$

The rise in the prison population is also likely a consequence of the political climate regarding crime and punishment which may have affected sentencing decision making. Unlike courts in other countries which have formally or informally adjusted sentencing practices in response to adverse prison conditions, courts in Ethiopia continue to use prison as a common sanction, even for minor crimes.

The only State response has been to grant unprincipled (yet necessary) periodic amnesties. Every September the Federal and regional governments pardon thousands of prisoners in order to reduce the prison population. Thus, in September 2018, a government minister acknowledged that in the previous two years, approximately 40,000 prisoners had been released in this way by executive decree. ${ }^{53} \mathrm{Al}$ though popular in African and some European countries, this solution is temporary, unprincipled, and fails to correct the fundamental cause of prison overcrowding: an excessive reliance on custody as a sanction. We return to explore remedial actions in the last part of this essay.

\section{PART II: THE SUPREME COURT SENTENCING GUIDELINE}

\subsection{The Structure of the Guideline}

Before describing the guideline functions, an overview of its structure may be helpful. The guideline comprises six parts, ${ }^{54}$ accompanied by

${ }^{51}$ For example, s 718 29d)-(e) of the Criminal Code of Canada states that "An offender should not be deprived of liberty, if less restrictive alternatives may be appropriate in the circumstances; and (e) all available sanctions other than imprisonment that are reasonable in the circumstances should be considered for all offenders, with particular attention to the circumstances of aboriginal offenders."

${ }^{52}$ Ministry of Justice, "Criminal Justice Policy of Federal Democratic Republic of Ethiopia", (Addis Ababa, Ministry of Justice 2011) p. 47.

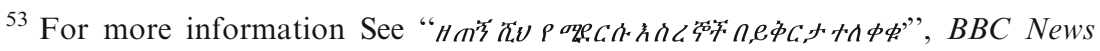
(Amharic) (10 September 2018) https://www.bbc.com/amharic/news-45470154.

${ }^{54}$ To summarise, the first part defines various terms, declares the purposes of the guideline and lists general principles that underpin the guideline. Part II contains 
two Sentencing tables containing lists of imprisonment ranges and other suggested penalties.

One of the first steps in the creation of a sentencing guidelines scheme is the establishment of an orderly ranking of punishments, arrayed in terms of their relative severity. Most sentencing guidelines commissions begin by constructing such a scale, usually based upon current sentencing practice and appellate jurisprudence. A ranking of penalties is crucial to a proportionality-based sentencing scheme because it permits courts to match offences with commensurately severe punishments. Unlike most sentence severity rankings which only include custodial sentences, the Ethiopian model incorporates noncustodial sanctions as well. This is an important advance: it ensures a degree of penal equivalence across different forms of sanction.

While the first Table lists levels of penalty for sanctions depriving liberty, the second provides penalty levels for fines. The former lists 39 penalty levels ranging from one-day compulsory labour to the death penalty. ${ }^{55}$ Level 1 deals only with compulsory work, levels 2 and 3 provide both imprisonment and compulsory labour. The levels from level 4 to 38 include imprisonment with differing ranges. The final, level 39, prescribes the death penalty. The Table also provides noncustodial sentencing options for levels $1-5$. Thus, in levels 1 to 5 , judges have the option of imposing alternatives to custody. The Sentencing Table lists 23 fine levels, extending from level 1 (up to $1,000 \mathrm{~EB}$ ) to 23 (a fine over 2,000,000 EB). ${ }^{56}$ The sentence ranges at the lower end of the Sentencing Table for penalties depriving liberty and life are much narrower than those at the upper end. This pattern recognizes the greater variation in crime seriousness of the more serious crimes. 57

Footnote 54 continued explanation regarding the sentencing tables, including sentence levels and the principles that guide the sentence ranges. Part III sets out offence seriousness categories with corresponding penalty levels. Part IV offers guidance on how to aggravate and mitigate the sentence while Part V lists steps that should be followed to determine the final sentence. Part VI contains miscellaneous provisions.

${ }^{55}$ For more complete information about levels of punishments depriving liberty, See Appendix 1 of the Revised Sentencing Guideline.

${ }^{56}$ For more complete information about levels of fine, see Appendix 2 of the Revised Sentencing Guideline.

${ }^{57}$ See Article 6 (3/a \&b), The Revised Sentencing Guideline. 


\subsection{Offence Seriousness Categories}

The English sentencing guidelines separate the key dimensions of harm and culpability by creating a two-dimensional structure. Each case is assigned to a level of harm and a level of culpability with the two dimensions contribute equally to the sentencing equation. Most of the Council's guidelines contain three categories of harm and culpability. ${ }^{58}$ In contrast, the Ethiopian guideline adopts a simpler, unidimensional structure: offences are divided into several levels or categories of offence seriousness. Each level is then linked to a proportionate sentence range. In this respect, the Ethiopian guideline reflects an offence-based version proportionality, and leaves less room for the court to take culpability into account.

The Ethiopian guideline contains detailed instructions as to how offence seriousness categories (hereafter simply "categories") should be selected, and it contains two approaches to determining these categories. While the first approach applies to offences for which the guideline prescribes categories, the second approach applies to offences for which the guideline does not provide categories. For the latter offences, the guideline offers guidance for determining the appropriate category. This is, however, a temporary solution until guidelines categories have been devised for all offences. In this respect the Court has followed the same approach as the Sentencing Council in England and Wales, namely to issue guidelines for different offences sequentially over time. This approach confers some benefits and creates some dangers, to which we return later in the article.

\subsection{Offences with Guideline Categories of Seriousness}

In developing the guideline, the drafters have pursued the same approach adopted in England and Wales, namely to assign priority to the most common offences. Accordingly, the first guideline provided offence seriousness categories for crimes accounting for approximately $80 \%$ of cases. ${ }^{59}$ At present, the revised guideline provides categories for offences committed against seven essential interests. ${ }^{60}$

\footnotetext{
${ }^{58}$ Sentencing Council of England and Wales: https://www.sentencingcouncil.org. $\mathrm{uk} /$.

${ }^{59}$ See Sentencing Guideline, Induction Training Module, Federal Justice Organs Professionals Training Center (available only in Amharic).

${ }^{60}$ Part three of the guideline list offence levels for crimes against the state (Article $241 \& 257$ ), crimes involving currencies, bonds and security documents (Article 356362), abuse of power (Article 407), crimes against life (Article 539-543), crimes
} 
The guideline contains three important elements - general narrative guidance followed by tables specifying offence seriousness categories with corresponding levels of punishment. The narrative guidance provided for each crime with categories plays a supplementary role in identifying the level of an offence. The guideline specifies categories of offences in the tables that follow. The tables specify relevant criminal law provisions, categories of offence, the elements of each offence category and the corresponding penalty level. The guideline divides offences into multiple offence seriousness categories, the minimum being only one (for article 556(1)) and the maximum being eleven for Uttering (Article 361(2) (a) ${ }^{61}$ In principle, the constitutive elements of crimes were the basis for the formation of the levels of offences in the guideline. However, in cases where these elements were deemed unclear, the drafters relied on the definition of that crime as provided in international treaties ratified by Ethiopia. ${ }^{62}$

\subsection{Guidance for Determining Penalty Levels for Offences with no Prescribed Categories}

The guideline also offers generic guidance for determining categories for crime with no prescribed offence categories in the guideline. When determining the sentence for these offences, the court must first determine the seriousness of the crime being sentenced. The guideline instructs the court to devise three broad seriousness categories: simple, intermediate and serious. ${ }^{63}$ The guideline does not enumerate the circumstances used to determine whether a particular offence is simple, intermediate, or serious. Courts are only required to state why the offence was assigned to a specific category. ${ }^{64}$ Nevertheless, it provides circumstances which the court may consider in determining

Footnote 60 continued

against person and health (Article 555-560), unlawful sending of Ethiopians for work abroad. (Article 598), crimes against sexual liberty and chastity (Article 620628), crimes against property: theft (Article $665 \& 669$ ), robbery (Article $670 \& 671$ ), fraudulent misrepresentation (Article 692), \& drawing of a cheque without sufficient funds (Article 693).

${ }^{61}$ See Article 13 (6) \& 1093), The Revised Sentencing Guideline.

${ }^{62}$ For instance, the constitutive elements of the crime of trafficking in person were adopted from the UN Protocol to Prevent, Suppress and Punish Trafficking in Persons, especially Women and Children See art 14 (5), The Revised Sentencing Guideline.

${ }^{63}$ Article 19(3) of the Revised Sentencing Guideline.

${ }^{64}$ Article 19 (4) of the Revised Sentencing Guideline. 
levels for an offence, including the circumstances of the offence, the level of harm and the degree of culpability. ${ }^{65}$ The list of factors is not exclusive or restrictive: courts are allowed to take other factors in their own discretion into account in determining offence levels.

\subsection{An Example of the Guideline in Practice}

This section describes how courts determine sentences by applying the procedure set out in the guideline. Consistent with the English guidelines $^{66}$, a court determines the sentence by following a series of steps.

\subsubsection{Methodology for Offences with Guideline Categories}

Several steps must be followed when determining sentence under the Ethiopian guideline system. The process of sentencing for offences with offence seriousness categories begins with assigning offence levels. $^{67}$

- Step One involves determining the offence seriousness category of the specific crime. At this step, the court will also be able to identify the penalty level corresponding the offence level identified by the court since the tables in the guideline stipulate the corresponding penalty levels along with levels of offence.

- At Step Two, the court identifies the applicable sentencing range for the level identified in Step One. It does so by identifying the applicable penalty level from the Sentencing Table appended to the guideline, which stipulates 39 levels. Each of the thirty-nine punishment levels has its own sentencing range.

- Step Three reminds the court to determine the type of imprisonment, either simple or rigorous imprisonment.

- Step Four calls on the court to consider relevant aggravating and mitigating circumstances. If no aggravating or mitigating circumstances are found, the court determines a provisional starting penalty within the range indicated in the penalty level identified in the previous step. If there are aggravating and mitigating circumstances, the court is required to adjust the penalty level before

${ }^{65}$ Article 19(5) of the Revised Sentencing Guideline.

${ }^{66}$ Roberts, J.V. and Rafferty, A. (2011) Sentencing Guidelines in England and Wales: Exploring the new Format. Criminal Law Review, 9: 680-689; Ashworth, A. and Roberts, J.V. (Eds.) (2013) Sentencing Guidelines: Exploring the English Model. Oxford: Oxford University Press.

${ }^{67}$ See Article 26(1), Revised Sentencing Guideline. 
determining a provisional starting penalty. The presence of aggravating and mitigating circumstances forces the court to move out of the initial penalty range selected by the court in the previous step.

- At steps five and six, the court aggravates the provisional sentence determined in accordance with the previous steps based on general and special aggravating circumstances accepted by the court.

- At step seven, the court reduces the penalty level reached in aggravation of the sentence by considering mitigating circumstances accepted by the court.

- Step Eight reminds the court of its discretion to convert imprisonment to compulsory work if the sentence of imprisonment imposed does not exceed six months.

- Step Nine reminds the court to follow the guideline when converting terms of imprisonment to a fine.

Finally, the English guidelines include a separate step in the guidelines methodology which requires courts to give reasons for the sentence to be imposed. This important step promotes the legitimacy of the sentence and facilitates any subsequent appellate review. No such requirement exists in the Ethiopian guidelines.

\subsubsection{Example: Willful Injury}

This section illustrates how the guideline works by using Article 556 of the Criminal Code, a provision that provides the constitutive elements of common willful injury and the applicable sentence. ${ }^{68}$ The sanction for the standard form of common willful injury under Article 556(1) is simple imprisonment not exceeding one year, or a fine, while aggravated forms are punishable with simple imprisonment from six months to three years. ${ }^{69}$ For the ordinary form of common willful injury, the guideline provides only a single offence category; for its aggravated forms, it provides four offence categories, based upon key characteristics of the offence. Appendix A illustrates

\footnotetext{
${ }^{68}$ Article 556 of the Criminal Code provides:(1) Whoever causes another to suffer an injury to body or health other than those specified in Article 555 above, is punishable, upon complaint, with simple imprisonment not exceeding one year, or with fine.(2) The crime is punishable, upon accusation, with simple imprisonment from six months to three years where:a) the criminal has used poison, a lethal weapon or any other instrument capable of infecting injuries; orb) the criminal has inflicted the injuries in breach of a duty, professional or other; orc) the victim is weak, sick or incapable of defending himself.
}

${ }^{69}$ Article 556(2) of the Criminal Code. 
the guideline for common willful injury. For example, if the crime involved a vulnerable victim, then it falls into seriousness level 3 of Article 556(2). This in turn attracts a sentence in the penalty level 9 range which runs from 16 months to 22 months.

Having identified the appropriate penalty level, the court either determines a provisional penalty within the range indicated in the Sentencing Table or adjusts the penalty level to reflect aggravating and mitigating circumstances. For example, a single general aggravating factor justifies an increase of one severity level; conversely, the presence of a single mitigating circumstance warrants a reduction of one level. After adjusting the punishment level based on the individual circumstances, the court decides the sentence within the range indicated in the final punishment level identified at the end of this process.

\subsection{Calculation of Sentence for Offences with no Prescribed Offence Seriousness Categories}

As noted above, the sentencing process for offences with no prescribed offence levels in the guideline starts with calculating offence levels. After having divided the offence into three seriousness categories, the court must determine the penalty level of the offence. This involves several steps. First, the court must consult the penalty prescribed for the offence in the Criminal Code. Second, the guideline requires the court to identify the penalty range in the specific provision consulted and divide it by four. In this way, courts can create four provisional penalty levels. In step 3, the court forms four sentencing ranges. This is accomplished by adding one quarter of the range specified in the Criminal Code incrementally and consecutively to the minimum penalty indicated by that provision. Adding the first $1 / 4$ to the minimum penalty indicated in the specific provision in the Criminal Code creates a sentencing range for penalty level 1 . This range becomes the sentencing range within which the court determines the provisional sentence for an offence the level of which was determined as simple by the court. The court follows a similar approach in order to construct the remaining three sentencing ranges. In this way, the court creates four penalty levels. If the court determines the seriousness level of an offence as intermediate, the penalty level that applies to this seriousness category will be level 2. Level 3 applies to an offence which was found by the court to be serious, while level 4 applies to exceptionally grave offences. 
After having identified the offence category, step 4 requires the court to determine a provisional sentence within the range formed following the above procedure. The fifth step instructs the court to locate the provisional sentence on the Sentencing Table and identify the level in which the provisional sentence falls. After this step, the steps for calculating the sentence are the same as those for offences with offence levels. In this way the guideline also provides structure even if the offence has not been stratified into categories of seriousness.

\subsection{The Role of Aggravating and Mitigating Factors}

The law recognizes two types of aggravating and mitigating circumstances: general and special circumstances. The former are deemed more central to the offence and therefore carry more weight than the latter in determining sentencing outcomes. The accused is deemed to be more dangerous when he acts in special than when he acts in general aggravating circumstances. ${ }^{70}$ Conversely, greater reduction of the sentence is warranted when the accused acts in special than when he acts in general mitigating circumstances. If the aggravating and mitigating circumstances are appropriately designated as either general or specific, this structure imparts useful additional guidance to courts. It also mirrors a feature of the English guidelines where sentencing factors are classified as sufficiently important to affect the choice of the offence category, or whether they should only affect the sentence within a given category's sentencing range. The former are "Step One" factors, the latter are considered only at Step two of the guidelines methodology where, as noted, they exercise less influence over the sentence imposed. ${ }^{71}$

When it comes to the application of sentencing factors, "double counting" of sentencing factors is prohibited when the circumstances are elements of the offences. ${ }^{72}$ In addition to circumstances specified by the Criminal Code, judges are also allowed to aggravate or mitigate sentences based on factors that are not expressly listed in the Criminal Code, but they must provide reasons for doing so. ${ }^{73}$

\footnotetext{
${ }^{70}$ Graven P., An introduction to Ethiopian penal law: (arts. 1-84 Penal Code), (1965, Faculty of Law Haile Selassie I University) p. 256.

${ }^{71}$ Roberts, J.V. and Rafferty, A. (2011) Sentencing Guidelines in England and Wales: Exploring the new Format. Criminal Law Review, 9: 680-689.

${ }^{72}$ See Article 82(2) \& 84(2) of the Criminal Code.

${ }^{73}$ Article 86 of The FDRE Criminal Code.
} 
However, since the Code does not specify the quantum of these factors, judges determine their impact on the sentence. As a result, the guideline contains specific procedures on how to apply these circumstances. First, the guideline restricts the number of aggravating and mitigating circumstances that judges could apply in any case to five factors. ${ }^{74}$ Second, if an aggravating circumstance is disputed, courts have the discretion to require evidence proving the factor to a criminal standard. ${ }^{75}$

The Ethiopian guideline thus offers some guidance as to the weight that should be accorded to aggravating or mitigating circumstances. Specifically, each general aggravating circumstance triggers an increase of one penalty level. ${ }^{76}$ This means that if a single aggravating circumstance is found, a court must move out of the provisional sentencing range. Conversely, each general mitigating circumstance accepted by the court requires a reduction of one penalty level from the provisional sentencing range. ${ }^{77}$

As noted above, special aggravating or mitigating circumstances carry less weight. The Code recognizes two special aggravating circumstances: concurrent offending and previous offending. ${ }^{78}$ The guideline does not alter the method of calculation of sentence in a case where the offender was convicted of multiple counts or was a recidivist. ${ }^{79}$ On the other hand, special mitigation is only warranted in a case where an individual was convicted of offences against the administration of justice which was committed due to a family relationship or close relation. (For example, when an individual fails to report or supplies false information to the competent authorities in order to protect one of his near relatives or marriage from a conviction, dishonor, or serious injury. ${ }^{80}$ ) In such cases, courts enjoy

\footnotetext{
${ }^{74}$ Art 21 (4) \& 23(1), The Revised Sentencing Guideline Cambridge: Cambridge University Press.

${ }^{76}$ Article 21(4) of the Revised Sentencing Guideline.

${ }^{77}$ Article 23(4) of the Revised Sentencing Guideline.

78 Article 85 of the Criminal Code.

${ }^{79}$ See Article 184 \& 188 of the Criminal Code.

${ }^{80}$ Article 83 of the Criminal Code.
}

${ }^{75}$ Art 26(1(g)), The Revised Sentencing Guideline. Ideally, the prosecution should be required to establish all aggravating factors to the criminal standard, if disputed by the defence. Some sentencing statutes such as the Sentencing Law in Israel have placed this procedural requirement on a statutory basis, and it is generally the norm across all common law jurisdictions; see Reitz in Roberts, J.V. (Ed.) (2011) Mitigation and Aggravation at Sentencing. Cambridge Studies in Law and Society. 
wide discretion and can reduce the sentence without any restriction. The court may even waive the sentence entirely. The guideline retains this discretion provided in the Code.

\subsubsection{Prior and Concurrent Multiple Convictions}

Prior convictions constitute the most important aggravating factor in both common and civil law jurisdictions. ${ }^{81}$ If the offender has prior convictions, it will then be at the discretion of the court to increase the penalty to the maximum for a given type of penalty, even by exceeding the sentencing range specified for the offence of conviction in the Code. In such cases, the only restriction is that the sentence must not exceed the ceiling for a given type of penalty. This is one area where the guideline should provide more guidance. If an individual was convicted of multiple current crimes, the court then determines the sentence for each crime and adds the sentence, provided that the result does not exceed the general maximum sentence of the type of sentence imposed by the court. The court then identifies the applicable sentencing range for this sentence and then aggravates or mitigates the sentence by applying general circumstances.

Sentencing offenders with multiple current and/ or multiple prior crimes is one of the most challenging aspects of sentencing. Opinions vary regarding the degree to which previous convictions should affect sentencing, as well as the kinds of prior crimes which justify a harsher sentence. Should all priors increase sentence severity, or only priors similar to the current offence? How long should prior crimes remain relevant before they lapse, and cease to count against the defendant at future sentencing hearings? The US guidelines provide a very structured approach to the use of previous convictions. ${ }^{82}$ This level of structure has been rejected in other guidelines, and may also be unwelcome in Ethiopian courts. However, some additional guidance would be useful.

Similarly, sentencing an offender currently facing multiple charges requires a court to consider the degree to which their sentences should be combined in a way that does not prove crushing to the offender, or

${ }^{81}$ See Roberts, J.V. and Herrendorf, S. (2019) The Role of Prior Convictions at Sentencing in Anglo-Saxon jurisdictions and Germany. In: K. Ambos et al., (eds.) (2019) Core Issues in Criminal Law and Criminal Justice. Volume 1. Cambridge: Cambridge University Press; Roberts, J.V. (2008) Punishing Persistent Offenders. Oxford: Oxford University Press.

${ }^{82}$ See Frase, R. and Roberts, J.V. (2019) Paying for the Past: Prior Record Enhancements in the US Sentencing Guidelines. New York: Oxford University Press. 
result in a total level of punishment much higher than that imposed for a more serious offence. ${ }^{83}$ Other guidelines offer some guidance on this complex problem in sentencing. The English Sentencing Council for example has issued a guideline specifically designed to guide courts sentencing offenders convicted of multiple crimes ${ }^{84}$ Here too, Ethiopian courts could benefit from more guidance, yet none is offered at present.

\subsection{Departing from the Guideline}

As with guideline schemes in other jurisdictions, courts are permitted to depart from either guideline-specified offence categories or from the guideline's method of calculating a sentence. ${ }^{85}$ This is permitted when the court finds the sentence levels specified in the guideline do not adequately reflect the circumstances of the offence or when the court believes that a sentence that would be imposed by applying the guideline sentence will not achieve the goals of punishment recognized by the law. ${ }^{86}$ The criteria for departure are comparable to those found in other guideline jurisdictions. Minnesota courts may depart from the guideline ranges only if they first find "substantial and compelling reasons" to justify a departure. In England and Wales, courts may depart from the guideline sentence recommendations when it would be "contrary to the interests of justice" to follow the recommended sentence. As with the Minnesota guidelines, courts in Ethiopia must indicate their reasons for departure in their decisions.

Although not expressly indicated in the guideline, it is reasonable to assume that a court is permitted to depart from the guideline when it finds the outcome of applying the guideline as either too harsh or too lenient. As it stands, it is unclear whether a court is bound to follow the method of calculation of sentence in the guideline when the court departs from the guideline when the offence of conviction dif-

${ }^{83}$ See Martin Wasik and Andrew Ashworth, Sentencing the Multiple Offender: In search of a "Just and Proportionate" sentence. In: Ryberg, J., Roberts, J.V., and de Keijser, J. (eds.) Sentencing Multiple Crimes. Studies in Penal Theory and Philosophy. New York: Oxford University Press. See more generally, essays in Ryberg, J., Roberts, J.V., and de Keijser, J. (eds.) (2017) Sentencing Multiple Crimes. Studies in Penal Theory and Philosophy. New York: Oxford University Press.

${ }^{84}$ Sentencing Council of England and Wales https://www.sentencingcouncil.org. uk/publications/item/offences-taken-into-consideration-and-totality-definitive-guide line/.

${ }^{85}$ Article 27(1) of the Revised Sentencing Guideline.

${ }^{86}$ Ibid. 
fers from the offence as specified in the guideline. Similarly, it is unclear whether a court can determine the offence category based on the guideline and depart from the method of calculation of sentencing specified in the guideline. Finally, the guideline establishes a referral mechanism in cases of departures, according to which courts are instructed to include an order in their decisions requiring a copy of the file to be sent to the Federal Supreme Court. ${ }^{87}$ This is intended to be used for further refinement of the guideline as this provides a database that may be used to identify the most common reasons for departures.

\section{PART III: CRITIQUES OF THE GUIDELINE AND PRO- POSALS FOR REFORM}

The Ethiopian guideline represents a significant step towards providing courts with greater guidance. However, in a number of respects the guidelines may be improved.

\subsection{Offence Levels}

One criticism is that some rules in the guidelines amend provisions in the Criminal Code $^{88}$, and that the Supreme Court does not have jurisdiction to make such amendments. This criticism stems from the guideline's approach to ranking of the seriousness of offences. Critics claim that the way some offences have been ranked in the guidelines is unprincipled and incompatible with the Code. ${ }^{89}$ Indeed, an evaluation of offences in the Criminal Code in light of the guidelines' approach supports this claim.

This can be illustrated by evaluating the guideline's approach to ranking the seriousness levels of common willful injury. The Criminal Code typically specifies levels (e.g., grave willful injury, common willful injury, extenuated willful injury, injuries caused by negligence) and specific acts that fall within each category. For instance, art. 556(2) of the Criminal Code prescribes an enhanced sentence of simple imprisonment from six months to three years when the crime of common willful injury has been committed by using poison or a lethal weapon, when the injuries were inflicted in breach of a pro-

\footnotetext{
${ }^{87}$ Article 27(3) of the Revised Sentencing Guideline.

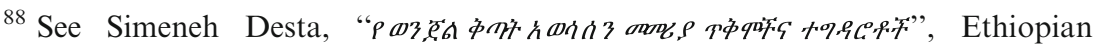
Press Agency (4 December 2018) at: https://press.et/?p=1025\#.

${ }^{89}$ Ibid.
} 
fessional duty or otherwise, or in case the victim was vulnerable, weak, sick or incapable of defending him or herself. However, the offence seriousness levels prescribed by the guideline for common willful under Article 556(2), appear to have been ranked on arbitrary and unprincipled basis.

The guideline's approach for ranking the seriousness level of the crime of common willful injury is incompatible with the Criminal Code and may result in unprincipled sentencing outcomes. First, the circumstances that the drafters applied for ranking the severity level of the crime from levels 1-4 are the same circumstances that were already specified from a-c of Article 556(2) of the Criminal Code. In prescribing the sentence, the Criminal Code does not make distinctions between those circumstances. As a result, the sentence prescribed by the Criminal Code applies to anyone who was found guilty of committing the crime in any of those circumstances. From a theoretical perspective, there is no justification to expect the harm produced by a poison or a lethal weapon to be less severe than a crime inflicted in breach of professional duty. There is no principled justification for the drafters of the guidelines to place the circumstances specified in the Code at different severity levels. Generally, when we look at Article 556(2) of the Code, it appears that the way the drafters ranked the severity levels of the crime make sense only if the drafters proceeded on the assumption that the Code listed those circumstances in order of their severity, from least severe to most severe. This appears to be the case as the circumstance under Article 556 (2)(a) of the Code is ranked as less severe than that of art. 556 (2)(b), and art. 556 (2)(b) than that of art. 556 (2)(c). This logic is, however, arbitrary and unprincipled.

\subsection{Determining Sentencing Ranges}

Another criticism relates to the guideline sentencing ranges. In certain cases, the range prescribed by the guideline falls below the minimum or rises above the maximum sentence stipulated by the Criminal Code. ${ }^{90}$ For instance, theft under art. 665 of the Criminal Code is punishable with simple imprisonment or rigorous imprisonment not exceeding 5 years. However, the guideline specifies 8 levels of offence for theft, and it prescribes starting sentence point 20 for offence level

\footnotetext{
${ }^{90}$ See Ayenew, Sefiew, "Ethiopian Sentencing Guidelines and Their application: A case study in Federal Courts", LL.M Thesis, (Addis Ababa: Addis Ababa University 2014) at 43.
} 
8, which means $4.5-5.5$ years. This range thus exceeds the maximum sentence of five years specified by the Code. In addition, courts may exceed this range further, to reflect aggravating circumstances. If this happens, the sentence will be significantly higher than the one stipulated by the legislature. This violates one of the cardinal constitutional protections in the Ethiopian Constitution which protects an offender from being subject to a heavier sentence than the applicable penalty specified in law. ${ }^{91}$ It also violates the Criminal Code, the principle of legality, and international human rights instruments ratified by Ethiopia. The rule in the guideline instructing judges to interpret the guideline in accordance with the Criminal Code cannot save it from being criticized for its unconstitutional features. ${ }^{92}$

\subsection{Need for Additional Guidance on Related Issues}

The guideline's failure to provide guidance on general sentencing issues may create confusion and inconsistent sentencing practice. For instance, the guideline does not provide guidance regarding sentencing for crimes of attempt ${ }^{93}$ and inchoate offences. As provided under Article 31 of the Criminal Code, courts have a range of discretionary sentencing powers in determining sentencing such crimes. ${ }^{94}$ In practice, an inconsistent approach has emerged: some judges impose the full sentence specified for the completed crime while others reduce the sentence by applying the Criminal Code. ${ }^{95} \mathrm{~A}$ similar problem may arise in the sentencing of a person who was convicted of inchoate crimes such as incitement and being an accessory. The Criminal Code provides that courts may reduce the sen-

\footnotetext{
${ }^{91}$ According to Article 22 (1) of the Constitution "No one shall be held guilty of any criminal offence on account of any act or omission which did not constitute a criminal offence at the time when it was committed. Nor shall a heavier penalty be imposed on any person than the one that was applicable at the time when the criminal offence was committed".

${ }^{92}$ See Simeneh Desta (above n 84).

${ }^{93}$ Ibid.

${ }^{94}$ Article 31. Discretionary Power of the Court."In determining the punishment to be imposed or where appropriate, in reducing it within the limit allowed by law, or, in special cases, in imposing no punishment where an attempt was abandoned or failed, the Court shall take into account all relevant circumstances. It shall in particular take into consideration the stage reached in the attempt and the danger it represented, the reasons why it failed, the motives which prompted the renunciation or the active repentance of the criminal, as well as his antecedents and the danger he represents to society."

95 See Simeneh Desta (above n 84)
} 
tence imposed on an accessory or instigator within the limits established by the law. ${ }^{96}$ Moreover, the guideline fails to provide guidance on how to calculate sentence for young offenders. The failure to provide guidance on these issues leads to inconsistent sentencing practices.

The success and challenges of the existing guidelines have so far not been established by empirical research. In contrast, the impact of the US and English guidelines has been extensively researched. ${ }^{97}$ Consequently, before establishing offence levels for the vast majority of offences that have no offence levels in the existing guidelines, the Supreme Court must be able to identify the achievements and challenges of the existing guidelines. Several issues, including the impact of the guidelines on the severity of sentences, the level of compliance with the guideline, the compatibility of the guidelines with the Criminal Code, and whether the guidelines have been able to achieve consistency and proportionately in sentencing, need to be addressed. The experience of jurisdictions that have fully implemented sentencing guidelines shows that establishing a sentencing guidelines body is a critical component of a sentencing guidelines system. These are normally permanent Commissions empowered to promulgate and amend sentencing guidelines, conduct research, collect data, and disseminate information regarding sentencing guidelines. ${ }^{98}$ Fortunately, the Court appears to be moving towards this direction. ${ }^{99}$

In addition, the guideline's approach for ranking offence seriousness categories should be reviewed and refined. As noted above, the determination of offence levels in the guideline appears rather ad hoc and unprincipled. Offences should be divided into categories of seriousness on a more systematic basis. One common method involves empirical research into the harms associated with different crimes, and forms of offence within the same legal definition. A

${ }^{96}$ See Article $36 \& 37$ of the Criminal Code.

${ }^{97}$ See essays in Ashworth, A. and Roberts, J.V. (Eds.) (2013) Sentencing Guidelines: Exploring the English Model. Oxford: Oxford University Press; Roberts, J.V. (ed.) (2015) Exploring Sentencing Practice in England and Wales. London: Palgrave Macmillan.

${ }^{98}$ See the U.S. Sentencing Commission, available at: https://www.ussc.gov/, The Sentencing Council for England and Wales, available at: https://www.sentencing council.org.uk/about-us/, O'Connell, Fiona, Comparative Research into Sentencing Guidelines Mechanism, Research and Information Service Research Paper, available at: http://www.niassembly.gov.uk/globalassets/documents/raise/publications/2011/ justice/6611.pdf.

${ }^{99}$ See Simeneh Desta (above n 84). 
systematic approach is necessary if the guidelines are to respect the principle of ordinal proportionality at sentencing. Research on the impacts of various offences may help to provide vital information in that direction. Similarly, evaluation and modification of sentencing ranges that go beyond the maximum or the minimum sentences prescribed the Criminal Code is necessary.

The guidelines treatment of aggravating and mitigating factors should also be reviewed. While the distinction between general and specific adds guidance regarding the importance these factors should have, the direction to increase or decrease by one level is unnuanced. The effect of any given factor cannot be established in advance, it must be left to judicial discretion to determine. In addition, assigning the same increment or decrement to aggravating and mitigating factors fails to allow sufficient discrimination between factors; some factors will carry much greater weight than others and a guideline scheme should not unduly restrict a court's discretion to recognize this fact. ${ }^{100}$ Finally, sentencing factors often interact, and the simplistically additive structure of the Ethiopian guideline fails to account for this possibility.

\subsection{Use of Custody as a Sanction}

We conclude with a comment on what may be the most pressing problem confronting the criminal justice system in Ethiopia: the high use of custody as a sanction and the ensuing high (and rising) prison population. The frequent use of imprisonment is surprising in light of the high cost of custody (relative to other sanctions). Why would one of the continent's poorest countries permit courts to employ custody so frequently? Mindful of the high economic and social cost of imprisonment, much wealthier countries have introduced mechanisms to restrict the use of custody as a sanction. ${ }^{101}$ Ethiopia could follow these approaches, and the sentencing guideline offers an effective means of achieving reductions in the volume of admissions to prison. Most US guidelines are sensitive to prison capacity; as prison overcrowding becomes apparent, Commissions can adjust guideline sentence rec-

${ }^{100}$ One example involves the guilty plea and the expression of remorse. These two separate factors often interact; some judges will see little strength in a remorse-based plea in mitigation if the offender has been convicted following a contested trial.

${ }^{101}$ See British Academy, A Presumption against Imprisonment. London: British Academy, 2014. Roberts, J.V. (2005) Reducing Prison Populations: Exploring Alternative Strategies. Reform. A Journal of National and International Law Reform, 86: $15-19$. 
ommendations in order to reduce both the number of people committed to custody and the amount of time they spend in prison. ${ }^{102}$ The Ethiopian guideline could be amended in a similar fashion, with equally salutary results. Alternatively, the Supreme Court could issue a practice memorandum reminding courts of the need to exercise restraint in the use of custody as a sanction. The principle of penal parsimony or restraint has been placed on a statutory footing in many common law jurisdictions ${ }^{103}$; the Ethiopian legislature could consider amending the Criminal Code in a similar fashion.

\section{CONCLUSION}

The Ethiopian guidelines are currently the most well-developed on the African continent. They are more detailed and prescriptive than the Kenyan and Ugandan equivalents, and as such they represent a useful model for other jurisdictions to consider for adaptation. Ultimately, only systematic research will reveal the extent to which they have achieved goals such as increasing the degree of consistency and proportionality at sentencing. Regardless, however, of the limitations of the guidelines, some of which have been identified here, Ethiopian judges are now better placed than their counterparts sentencing offenders before the creation of the guidelines.

\section{OPEN ACCESS}

This article is distributed under the terms of the Creative Commons Attribution 4.0 International License (http://creativecommons.org/ licenses/by/4.0/), which permits unrestricted use, distribution, and reproduction in any medium, provided you give appropriate credit to the original author(s) and the source, provide a link to the Creative Commons license, and indicate if changes were made.

${ }^{102}$ In contrast, in constructing its guidelines the English Sentencing Council do not consider the size of the prison population; see Roberts, J.V. and Ashworth, A. (2016) The Evolution of Sentencing Policy and Practice in England and Wales, 19962015. pp. 307-356 in: M. Tonry (ed.) Sentencing Policies and Practices in Western Countries. Comparative and Cross-National Perspectives. New York: Oxford University Press.

${ }^{103}$ Roberts, J.V. and Baker, E. (2008) Sentencing Structure and Reform in Common Law Jurisdictions. In: S. Shoham, O. Beck, and M. Kett (eds.). International Handbook of Penology and Criminal Justice. New York: Taylor and Francis. 


\section{APPENDIX A: EXAMPLE OF ETHIOPIAN OFFENCE- SPECIFIC GUIDELINE: COMMON WILLFUL INJURY $(\text { ARTICLE } 556 \text { (1) \& } 556(2))^{104}$}

\begin{tabular}{|c|c|c|c|}
\hline $\begin{array}{l}\text { Description of Conduct } \\
\text { determining Offence } \\
\text { Seriousness Category }\end{array}$ & $\begin{array}{l}\text { Offence } \\
\text { Seriousness } \\
\text { Category }\end{array}$ & $\begin{array}{l}\text { Imprisonment: Starting } \\
\text { Sentence level and range }\end{array}$ & $\begin{array}{l}\text { FineStarting } \\
\text { Sentence } \\
\text { level and range }\end{array}$ \\
\hline $\begin{array}{l}\text { Intentionally causing injury to } \\
\text { another person }\end{array}$ & 1 & $\begin{array}{l}\text { From } 10 \text { days- } \\
6 \text { months of } \\
\text { imprisonment or From } \\
10 \text { days }-6 \text { months } \\
\text { of compulsory labour }\end{array}$ & Up to 1,000 \\
\hline $\begin{array}{l}\text { Use of poison, a lethal weapon, } \\
\text { or other instrument } \\
\text { capable of inflicting injury }\end{array}$ & 1 & $\begin{array}{l}\text { From } 6 \text { months- } 1 \text { year } \\
\text { of imprisonment }\end{array}$ & Up to 2,000 \\
\hline $\begin{array}{l}\text { Injuries were inflicted in } \\
\text { breach of a duty, } \\
\text { professional or otherwise }\end{array}$ & 2 & $\begin{array}{l}\text { From } 1 \text { year-18 months } \\
\text { imprisonment }\end{array}$ & \\
\hline $\begin{array}{l}\text { Victim was vulnerable, weak, } \\
\text { sick, or incapable } \\
\text { of defending him or herself. }\end{array}$ & 3 & $\begin{array}{l}\text { From } 16 \text { months to } \\
22 \text { months } \\
\text { imprisonment }\end{array}$ & \\
\hline $\begin{array}{l}\text { The victim was weak, sick or } \\
\text { incapable of defending } \\
\text { himself or the offence was } \\
\text { inflicted in breach } \\
\text { of a duty, professional or } \\
\text { otherwise. }\end{array}$ & 4 & $\begin{array}{l}\text { From } 20 \text { months to } \\
26 \text { months } \\
\text { of imprisonment }\end{array}$ & \\
\hline
\end{tabular}

Publisher's Note Springer Nature remains neutral with regard to jurisdictional claims in published maps and institutional affiliations.

${ }^{104}$ Article 13 of the Revised Sentencing Guideline. 